\title{
MANUSIA SEBAGAI KHALIFAH DALAM PERSFEKTIF ISLAM
}

\author{
Rahmat Ilyas ${ }^{1}$
}

\begin{abstract}
Human existence as a creature of God's creation on this earth has an important role in its function as a vicegerent on earth. Allah not only regulates the life associated with the worship of God, but God also regulate how humans perform its role on this earth as caliph who aims to be the safety of the world and the hereafter.

In the Islamic concept, man is the vicegerent namely as a representative, a replacement or a god in advance bumi.dengan ambassador of his position as Caliph of Allah on earth, man will be held accountable before him. About how he was a holy duty caliphate. Therefore, in executing the responsibilities that humans are equipped with a variety of potential as a mind that provides the ability for humans to do so
\end{abstract}

Keywords: human, Islamic Perspective

\section{A. Pendahuluan}

Agama Islam, agama yang kita anut dan dianut leh ratusan juta kaum muslimin diseluruh dunia, merupakan way of life yang menjamin kebahagiaan hidup pemeluknya di dunia dan di akhirat kelak. Ia mempunyai satu sendi utama yang esensial berfungsi memberi petunjuk kejalan yang sebaikbaiknya. Hal ini sejalan dengan firman Allah Stw dalam Surat Al-Israa ayat 9:

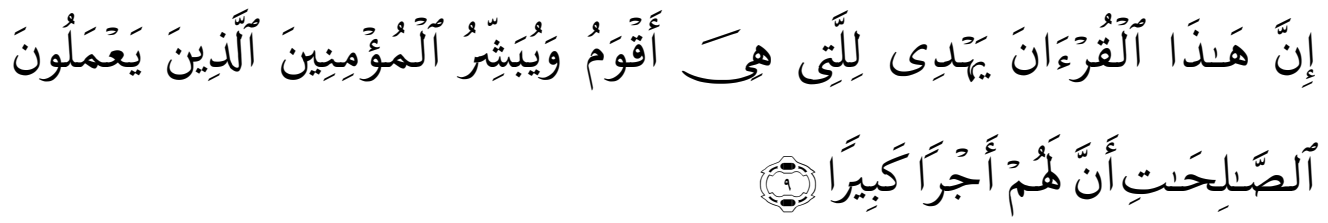

${ }^{1}$ Dosen Jurusan Syariah dan Ekonomi Islam STAIN Syaikh Abdurrahman Siddik Bangka Belitung 
"Sesungguhnya Al Quran ini memberikan petunjuk kepada (jalan) yang lebih lurus dan memberi khabar gembira kepada orang-orang Mu'min yang mengerjakan amal saleh bahwa bagi mereka ada pahala yang besar"

Al-qur'an memberi petunjuk dalam persoalan-persoalan akidah, syariah dan akhlak, dengan jalan meletakkan dasar-dasar prinsip mengenai persoalan-persoalan tersebut.

Alquran menempuh berbagai cara guna mengantar manusia kepada kesempurnaan kemanusiaannya antara lain dengan mengemukakan kisah faktual atau simbolik. Kitab Suci Alquran tidak segan mengisahkan "kelemahan manusiawi", namun itu digambarkannya dengan kalimat indah lagi sopan tanpa mengundang tepuk tangan, atau membangkitkan potensi negatif, tetapi untuk menggaris bawahi akibat buruk kelemahan itu, atau menggambarkan saat kesadaran manusia menghadapi godaan nafsu dan setan.

Keberadaan manusia sebagai salah satu mahkluk ciptaan Tuhan di muka bumi ini mempunyai peranan penting dalam menjalankan fungsinya sebagai khalifah dimuka bumi ini. Allah swt tidak hanya mengatur tentang kehidupan yang berkaitan dengan ibadah kepada Tuhan, tetapi Allah juga mengatur bagaimana manusia menjalankan perannya diatas muka bumi ini sebagai khalifah yang bertujuan untuk dapat keselamatan dunia dan akhirat.

\section{B. Makna Khalifah dalam Alquran dan Hadis}

Kata khalifah dalam bentuk tunggal terulang dua kali dalam al-qur'an yaitu pertama dalam surah Al-Baqarah ayat 30

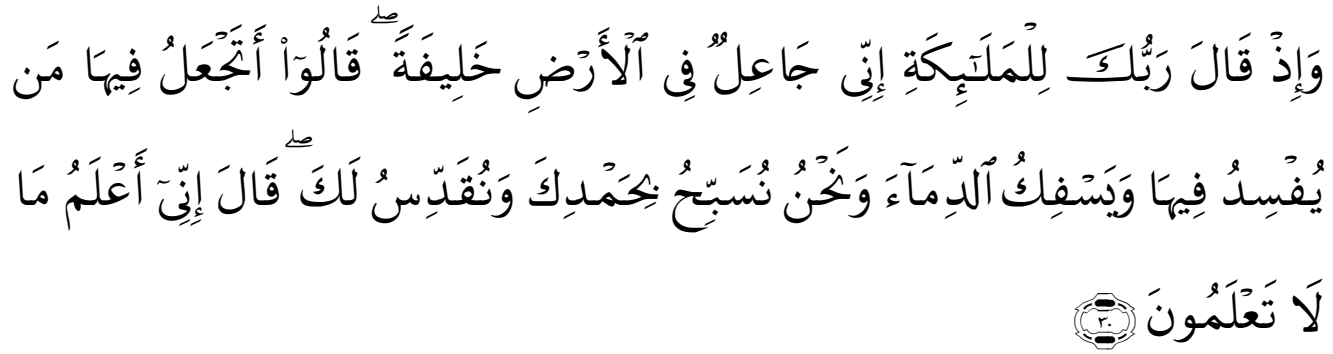


"Ingatlah ketika Tuhanmu berfirman kepada para Malaikat: "Sesungguhnya Aku hendak menjadikan seorang khalifah di muka bumi." Mereka berkata: "Mengapa Engkau hendak menjadikan (khalifah) di bumi itu orang yang akan membuat kerusakan padanya dan menumpahkan darah, padahal kami senantiasa bertasbih dengan memuji Engkau dan mensucikan Engkau?" Tuhan berfirman: "Sesungguhnya Aku mengetahui apa yang tidak kamu ketahui."

Pengertian khalifah dalam ayat diatas, menurut ar-R<azi yang dikutip oleh. Umar shihab ada dua: pertama Adam sebagai pengganti jin untuk menempati dunia, setelah jin ditiadakan sebagai penghuni bumi terdahulu. Kedua Adam adalah penguasa Bumi, sebagai pengganti Allah dalam menegakkan hukum-hukumnya diatas bumi. ${ }^{2}$

Muhammad Baqir al-S<adar sebagaimana yang dikutip oleh Quraish Shihab mengemukakan bahawa kekhalifahan yang terkandung dalam ayat diatas mempunyai tiga unsur yang saing terkait ditambahkan unsur keempat yang berada diluar, namun dapat menentukan arti kekhalifahan dalam pandangan al-qur'an. Ketiga unsur tersebut yaitu:

1. Manusia, yang dalam hal ini dinamai khalifah

2. Alam raya, yang ditunjuk oleh ayat Al-Baqarah sebagai ardh

3. Hubungan antara manusia dan alam dan segala isinya termasuk manusia

4. Yang berada diluar digambarkan dengan kata inni> ja'il/inna> ja'alnaka> khalifat, yaitu yang memberi penugasan, yakni Allah swt. ${ }^{3}$ dan yang kedua surah As-Shad ayat 26

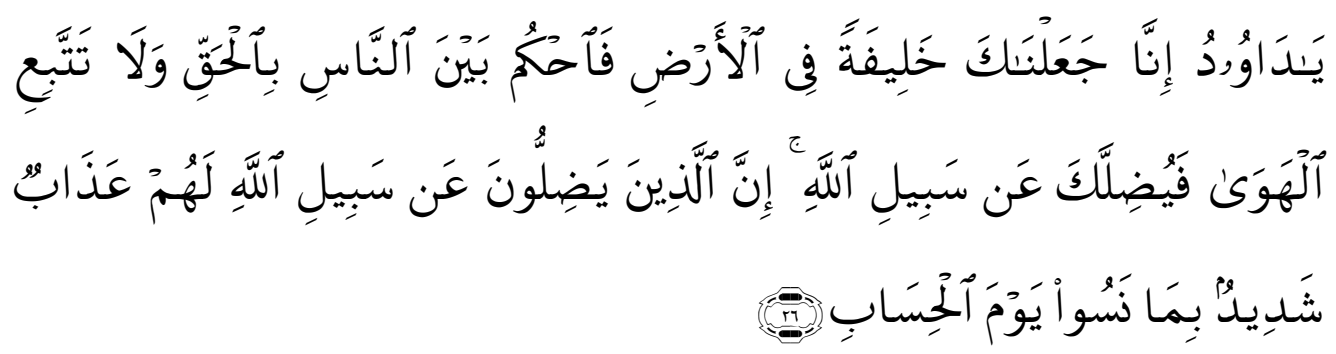

\footnotetext{
${ }^{2}$ Umar Shihab, Kontekstualitas Al-Qur,an; Kajian Tematik Ayat-ayat Hukum dalam AlQur'an, (Jakarta, Penamadani, 2005), h. 121

3 M.Quraish Shihab, Membumikan Al-Qur'an, (Bandung, Mizan, 2013), h. 246
} 
"Hai Daud, sesungguhnya Kami menjadikan kamu khalifah (penguasa) di muka bumi, maka berilah keputusan (perkara) di antara manusia dengan adil dan janganlah kamu mengikuti hawa nafsu, karena ia akan menyesatkan kamu dari jalan Allah. Sesungguhnya orang-orang yang sesat dari jalan Allah akan mendapat azab yang berat, karena mereka melupakan hari perhitungan."

Dalam ayat ini khalifah diartikan sebagai

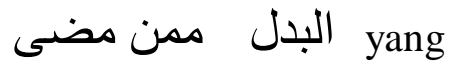
berarti pengganti dari orang-orang yang terdahulu ${ }^{4}$

Ayat yang lain juga menyebutkan dalam Surat az Zukhruf ayat 60

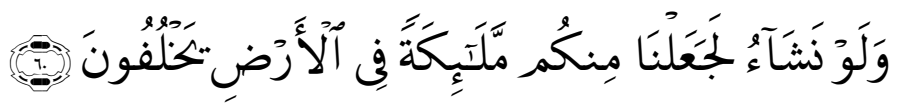

"Dan kalau Kami kehendaki benar-benar Kami jadikan sebagai gantimu di muka bumi malaikat-malaikat yang turun temurun."

Khalifah yang dimaksud dalam ayat ini yaitu an niya>bah yang berarti perwakilan. ${ }^{5}$

Selain itu terdapat dua bentuk plural atau jamak yang digunakan oleh al-qur'an dalam kata khalifah yaitu:

1. Kata khala> if yang terulang sebanyak empat kali dalam alquran yaitu dalam surah:

a) Al-An-am ayat 165

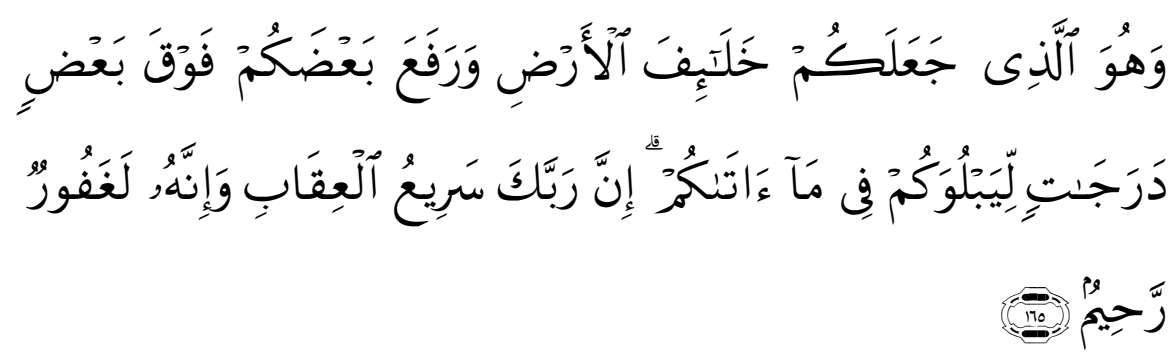

${ }^{4}$ Al-Husain Ibn Muhammad al-D<amaghani>, Qamus al-Qur'a>n aw Isla $>h$ al-Wuju>h wa an-Naza >ir fi> alqur'a>n al-Kari>m, (Beirut: $\mathrm{D}<$ aruilmi lil Mala>yi>n, 1980), h.162

5 Ar-Ra>ghib al-Ashfahani, Al-Mufrada>t fi Gha>rib Alqur'an (Tanpa Kota: Maktabah Nazar Musthofa al-Baz, Juz 1,tt), h. 207 
"Dan Dia lah yang menjadikan kamu penguasa-penguasa di bumi dan Dia meninggikan sebahagian kamu atas sebahagian (yang lain) beberapa derajat, untuk mengujimu tentang apa yang diberikan-Nya kepadamu. Sesungguhnya Tuhanmu amat cepat siksaan-Nya dan sesungguhnya Dia Maha Pengampun lagi Maha Penyayang."

Makna خَلَََفِف dalam ayat di atas adalah jamak dari kata khalifah, yakni sebagian diantara kamu mengganti sebagian lainnya dalam masalah kekhalifahan. ${ }^{6}$

b) Yunus ayat 14

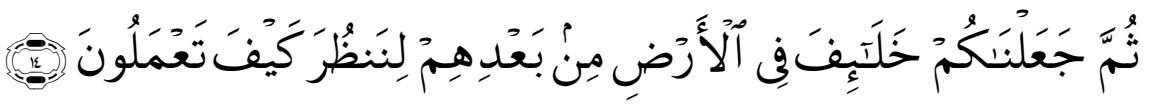

"Kemudian Kami jadikan kamu pengganti-pengganti (mereka) di muka bumi sesudah mereka, supaya Kami memperhatikan bagaimana kamu berbuat.",

Ayat ini pertama ditujukan kepada Quraisy, karena telah mewarisi pusaka kaum "Ad dan Samud". Tetapi hal semacam ini bisa berlaku umum. Dan itulah yang dialami dinasti bani Abbas pada masa $\mathrm{Ha}>$ run ar-R<asyid, pada masa kekuasaan Islam di Spanyol atau pada masa kekuasaan Turki sedang berada dalam puncak kemakmurannya, dan sudah tentu lepas dari soal kekuasaan politik, berlaku juga pada kaum muslimin dan yang bukan muslimin masa kita sekarang. ${ }^{8}$

c) Yunus ayat 73

6 Imam Jala>1 al-Di>n Al-Mahali dan Imam Jalal al-Di>n As-S<uyuthi, Tafsir Jala>lain Jilid 1,( Bandung, Sinar Baru Algensindo, 2014), h. 580 281

7 Departemen Agama, Al-Qur'an dan Terjemahan, (Surabaya, Mekar Surabaya, 2004), h.

${ }^{8}$ Abdullah Yusuf Ali, Qur'an Terjemahan dan Tafsirnya, (Jakarta, Pustaka Pirdaus, 1993), h. 487 


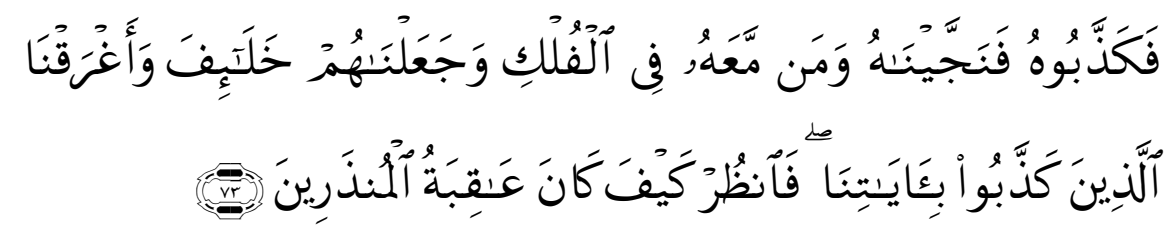

"Lalu mereka mendustakan Nuh, maka Kami selamatkan dia dan orang-orang yang bersamanya di dalam bahtera, dan Kami jadikan mereka itu pemegang kekuasaan dan Kami tenggelamkan orang-orang yang mendustakan ayat-ayat Kami. Maka perhatikanlah bagaimana kesesudahan orang-orang yang diberi peringatan itu. ,"9

d) Fathir ayat 39

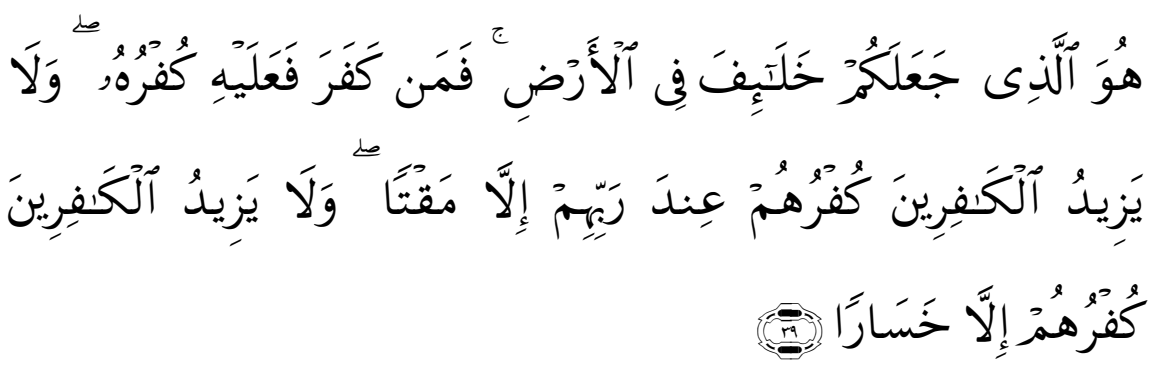

"Dia-lah yang menjadikan kamu khalifah-khalifah di muka bumi. Barangsiapa yang kafir, maka (akibat) kekafirannya menimpa dirinya sendiri. Dan kekafiran orang-orang yang kafir itu tidak lain hanyalah akan menambah kemurkaan pada sisi Tuhannya dan kekafiran orang-orang yang kafir itu tidak lain hanyalah akan menambah kerugian mereka belaka."

Lapaz Khala > 'if adalah bentuk jamak dari kata Khalifah yakni dia mengganti sebagian diantara kalian dengan yang lain yaitu generasi demi generasi. ${ }^{10}$

2. Kata Khulafa terulang sebanyak tiga kali dalam Alquran yakni terdapat dalam surah:

a) al-A'raf ayat 69

${ }^{9}$ Ibid, h. 291

${ }^{10}$ Imam Jala>1 al-Di>n Al-Mahali dan Imam Jalal al-Din As-S<uyuthi, Tafsir Jala>lain Jilid 2,( Bandung, Sinar Baru Algensindo, 2014), h. 580 


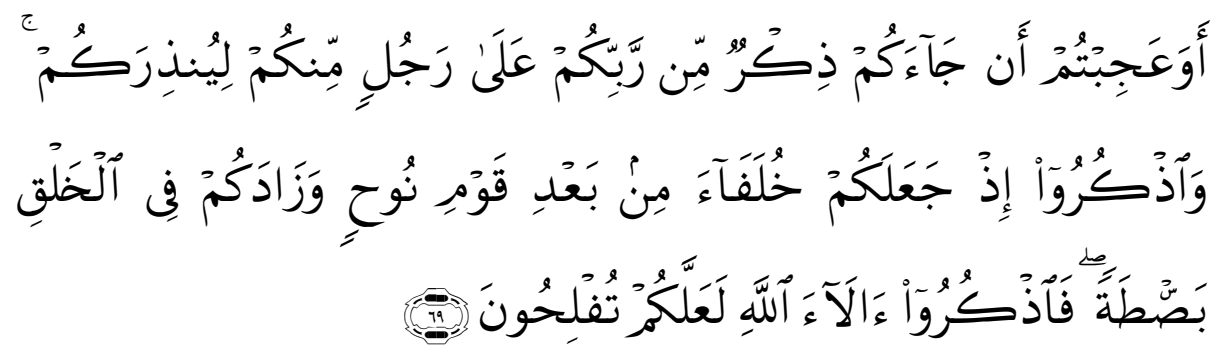

"Apakah kamu (tidak percaya) dan heran bahwa datang kepadamu peringatan dari Tuhanmu yang dibawa oleh seorang laki-laki di antaramu untuk memberi peringatan kepadamu? Dan ingatlah oleh kamu sekalian di waktu Allah menjadikan kamu sebagai penggantipengganti (yang berkuasa) sesudah lenyapnya kaum Nuh, dan Tuhan telah melebihkan kekuatan tubuh dan perawakanmu (daripada kaum Nuh itu). Maka ingatlah nikmat-nikmat Allah supaya kamu mendapat keberuntungan. ",1

Kata khulafa'a adalah bentuk jamak dari kata khalifah yang pada mulanya berarti yang mengganti atau yang datang sesudah siapa yang datang sebelumnya. ${ }^{12}$

b) al-A'raf ayat 74

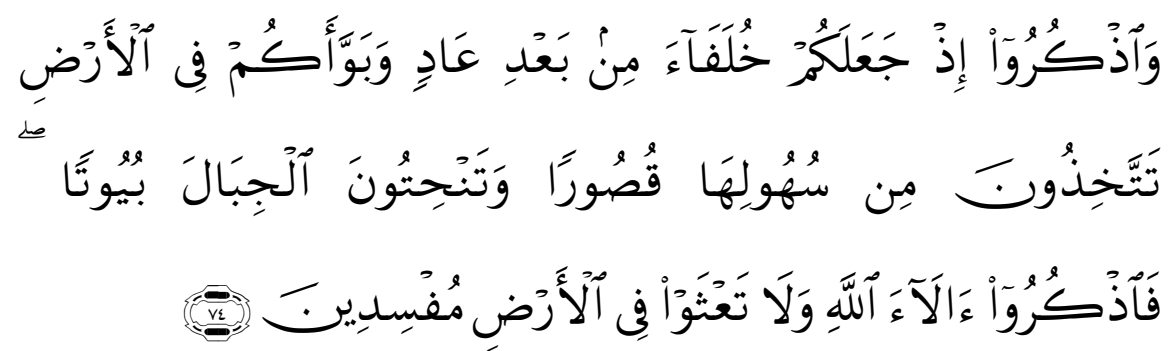

"Dan ingatlah olehmu di waktu Tuhan menjadikam kamu pengganti-pengganti (yang berkuasa) sesudah kaum 'Aad dan memberikan tempat bagimu di bumi. Kamu dirikan istana-istana di tanah-tanahnya yang datar dan kamu pahat gunung-gunungnya untuk dijadikan rumah; maka ingatlah nikmat-nikmat Allah dan janganlah kamu merajalela di muka bumi membuat kerusakan."13

c) an-Naml ayat 62

\footnotetext{
11 Departemen Agama, Al-Qur'an, h. 214

12 M.Quraish Shibab, Tafsir Al-Misbah Vol 4, (Jakarta, Lentera Hati, 2012), h.169

13 Ibid, h. 215
} 


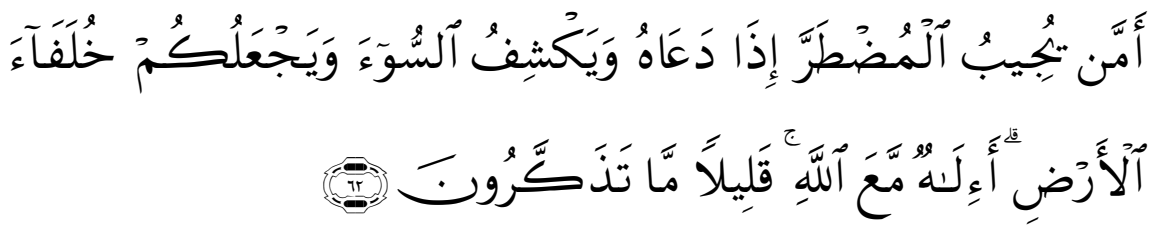

"Atau siapakah yang memperkenankan (doa) orang yang dalam kesulitan apabila ia berdoa kepada-Nya, dan yang menghilangkan kesusahan dan yang menjadikan kamu (manusia) sebagai khalifah di bumi Apakah disamping Allah ada tuhan (yang lain)? Amat sedikitlah kamu mengingati(Nya)."

Makna lafaz Khulafa > al-Ardi pada surat An-Naml ayat 62 diatas mengandung makna fi>, maksudnya setiap generasi menjadi pengganti generasi sebelumnya. ${ }^{14}$

Keseluruhan kata tersebut berakar dari kata khulafa yang pada mulanya berarti "dibelakang" darisini kata khalifah seringkali diartikan sebagai "pengganti" (karena yang menggantikan selalu berada atau datang dibelakang, sesudah yang digantikan).

Dalam konsep Islam, manusia adalah khalifah yakni sebagai wakil, pengganti atau duta tuhan di muka bumi.dengan kedudukannya sebagai khalifah Allah swt dimuka bumi, manusia akan dimintai tanggungjawab dihadapannya. Tentang bagaimana ia melaksanakan tugas suci kekhalifahannya. Oleh sebab itu dalam melaksanakan tanggungjawab itu manusia dilengkapi dengan berbagai potensi seperti akal pikiran yang memberikan kemampuan bagi manusia berbuat demikian. ${ }^{15}$

Kata khalifah juga mengandung makna pengganti nabi Muhammad saw dalam fungsinya sebagai kepala Negara, yaitu pengganti Nabi Saw dalam jabatan kepala pemerintahan dalam Islam baik urusan agama maupun dunia. ${ }^{16}$

Seperti yang telah di sampaikan di atas, ayat-ayat yang berbicara tentang pengangkatan khalifah dalam Alquran ditujukan kepada Nabi

\footnotetext{
${ }^{14}$ Ibid, h. 1619

${ }^{15}$ Dewan Redaksi Ensiklopedi Islam, Ensiklopedi Islam Jiid 3, (Jakarta, PT Ichtiar Baru van Hoeve, 2003), h. 35

${ }^{16}$ Ibid.
} 
Adam dan Nabi Daud. Khalifah pertama adalah manusia pertama (Adam) dan ketika itu belum ada masyarakat manusia, berbeda dengan keadaan pada masa Nabi Daud. Beliau menjadi khalifah setelah berhasil membunuh Jalut.

Ayat Sesungguhnya Aku akan mengangkat khalifah di bumi (QS Al-Baqarah 2: 30 menginformasikan juga unsur-unsur kekhalifahan sekaligus kewajiban sang khalifah. Unsur-unsur tersebut adalah (1) bumi atau wilayah, (2) khalifah (yang diberi kekuasaan politik atau mandataris), serta (3) hubungan antara pemilik kekuasaan dengan wilayah, dan hubungannya dengan pemberi kekuasaan (Allah swt.). Kekhalifahan itu baru dinilai baik apabila sang khalifah memperhatikan hubungan-hubungan tersebut. $^{17}$

Selain ayat-ayat di atas terdapat beberapa hadis yang membicarakan tentang khalifah, diantaranya:

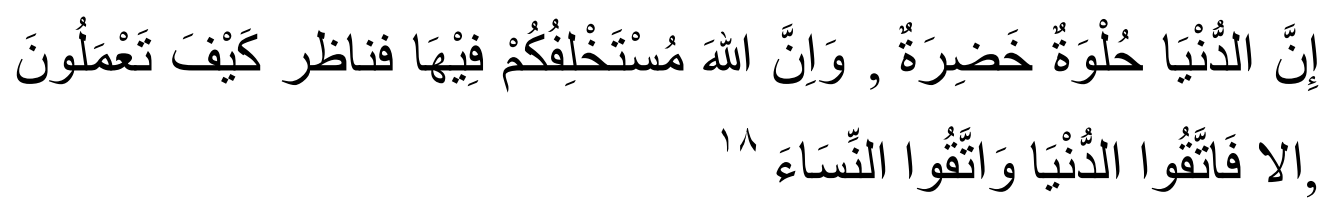

“...Sesungguhnya dunia manis dan hijau, dan sesungguhnya Allah akan menjadikan kalian sebagai pemimpinnya. maka (Allah) akan memperhatikan apa yang kalian lakukan, ingat, takutlah pada dunia, dan takutlah pada wanita.....

Hadis lain nabi Muhammad saw bersabda:

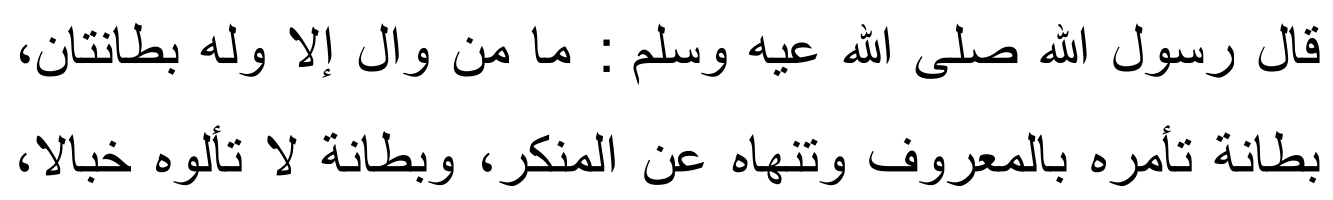

\footnotetext{
${ }^{17}$ M. Quraish Shihab, Wawasan Al-Quran Tafsir Maudhu'i atas Pelbagai Persoalan Umat, (Bandung, Mizan, 1996), h. 416

${ }_{18}$ Muhammad bin Isa bin Sauroh AtTirmizi>, Sunan At Tirmizi>, (Riyad, Mukatabah Ma'arif, cet 1, tt), h.496. Hadis ini juga terdapat dalam kitab shoheh muslim bab kebanyakan pendudukan surga adalah orang miskin dengan redaksi yang sedikit berbeda.
} 


\section{فمن وقي شـرها، فقد وقي، وهو من التي تغلب عليه منهما (روه ألنساء)}

Artinya: Rasulullah shallallahu 'alaihi wasallam bersabda: "Tidak ada seorang pemimpinpun kecuali ia memiliki dua orang teman karib, seorang teman yang menyuruhnya berbuat kebaikan dan melarangnya dari perbuatan mungkar, dan seorang teman yang mengajaknya berbuat kerusakan, maka barangsiapa yang terjaga dari keburukannya maka ia telah terjaga dan ia termasuk diantara yang menang diantara keduanya."

\section{Alasan Menjadikan Manusia sebagai Khalifah}

Manusia adalah mahkluk sentral di Planet ini.selain penciptaannya yang paling sempurna dan seimbang, mahkluk-mahkluk lain yang ada seperti hewan dan tumbuh-tumbuhan diciptakan untuk kepentingannya, baik secara langsung maupun tidak langsung. Hak pemakmuran dan pengelolaan bumi beserta isinya diberikan kepada manusia sebagai konsekuensi logis atas kesediaannya memangku amanah Allah. ${ }^{20}$

Alquran dalam ungkapannya yang sederhana namun tegas menekankan individualitas dan uniknya manusia, dan mempunyai pandangan yang pasti tentang peran dan nasib manusia sebagai suatu kesatuan hidup. Adalah akibat dari pandangan bahwa manusia adalah suatu individualitas yang unik yang menjadikan mustahil bagi indvidu itu untuk menangung beban orang lain, dan ia hanya berhak menerima buah atau akibat dari perbuatannya sendiri.

Ada empat sifat manusia yang diterangkan dalam al-qur'an:

Pertama, bahwa manusia itu adalah mahkluk yang dipilih oleh tuhan.

Dalam surat Tahaa ayat 122

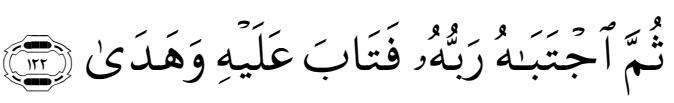

${ }^{19}$ Abu> Abd ar-Rahman Ahmad Bin Syu'aib bin Ali> Assyahir bi an-Nasai ,Sunan Nasai (Riyad, Maktabah al-Ma'a>rif , tt),h. 648

${ }^{20}$ Lajnah Pentashihan Mushaf Al-Qur'an, Tafsir Al-qur'an Tematik (Spritualitas dan Ahklak), (Jakarta, Aku Bisa, 2012), h. 37 
"Kemudian Tuhannya memilih dia maka Dia menerima taubatnya dan memberinya petunjuk. "21

Kedua bahwa manusia dengan segala kelalaiannya diharapkan supaya menjadi wakil tuhan di bumi (khalifah). Dalam surat al-baqarah ayat 30:

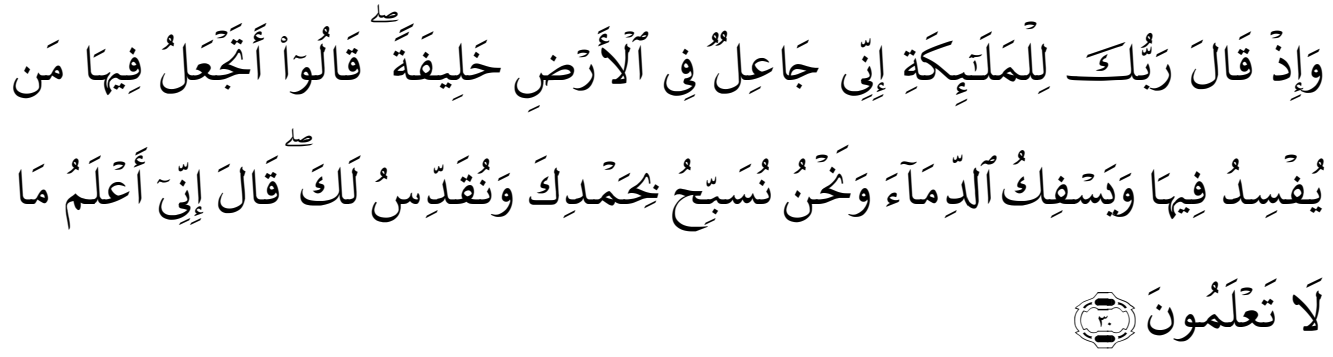

Ingatlah ketika Tuhanmu berfirman kepada para Malaikat: "Sesungguhnya Aku hendak menjadikan seorang khalifah di muka bumi. ${ }^{22 " ~ M e r e k a ~ b e r k a t a: ~}$ "Mengapa Engkau hendak menjadikan (khalifah) di bumi itu orang yang akan membuat kerusakan padanya dan menumpahkan darah, padahal kami senantiasa bertasbih dengan memuji Engkau dan mensucikan Engkau?" Tuhan berfirman: "Sesungguhnya Aku mengetahui apa yang tidak kamu ketahui." ${ }^{23}$

Dalam tafsir al- Misbah dijelaskan bahwa kata Khalifah pada mulanya berarti yang menggantikan atau yang datang sesudah siapa yang datang sebelumnya. Atas dasar ini, ada yang memahami kata khalifah disini dalam arti yang menggantikan Allah dalam menegakkan kehendak-Nya dan menerapkan ketetapan-ketetapan-Nya, tetapi bukan karena Allah tidak mampu atau menjadikan manusia berkedudukan sebagai tuhan, namun karena Allah bermaksud menguji manusia dan memberinya penghormatan. Adalagi yang memahaminya dalam art yang menggantikan mahkluk lain dalam menghuni bumi ini. Betapapun, ayat ini menunjukkan bahwa kekhalifahan terdiri dari wewenang yang dianugerahkan Allh swt, makhluk yang diserahi tugas yakni Adam as dan anak cucunya. Serta wilayah tempat bertugas, yakni bumi yang terhampar ini. Jika demikian, kekhalifahan mengharuskan

${ }^{21}$ Departemen Agama, Al-Qur'an, h. 445

${ }^{22}$ Yang akan mewakili Aku (Tuhan) dalam melaksanakan hukum-hukum atau peraturanperaturan $\mathrm{Ku}$ (Tuhan) padanya (yaitu Adam). Imam Jala>l al-Di>n al-Mahali dan Imam Jala>1 alDi>n As-Suyu>ti>, Tafsir Jalalain Jilid I........, h. 17

${ }^{23}$ Departemen Agama, Al-Qur'an, h. 6 
mahkluk yang diserahi tugas itu melaksanakan tugasnya sesuai dengan petunjuk Allah yang memberinya tugas dan wewenang. Kebijaksanaan yang tidak sesuai dengan kehendak-Nya adalah pelanggaran terhadap makna dan tugas kekhalifahan. ${ }^{24}$

Dalam surah al-an'am ayat 165:

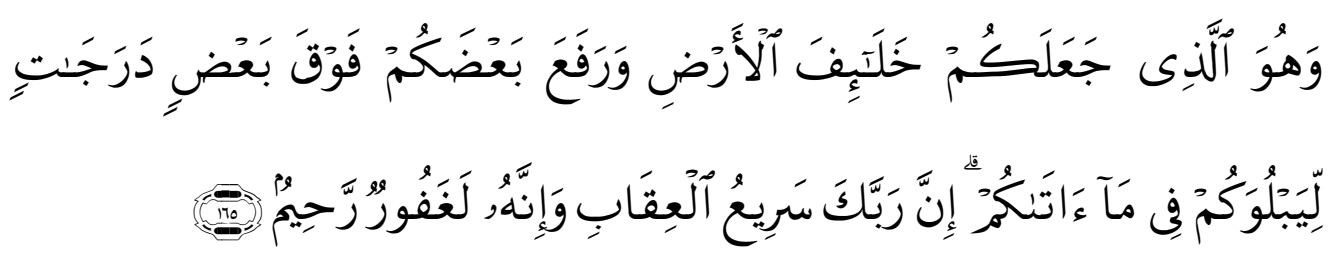

"Dan Dia lah yang menjadikan kamu penguasa-penguasa di bumi dan Dia meninggikan sebahagian kamu atas sebahagian (yang lain) beberapa derajat, untuk mengujimu tentang apa yang diberikan-Nya kepadamu. Sesungguhnya Tuhanmu amat cepat siksaan-Nya dan sesungguhnya Dia Maha Pengampun lagi Maha Penyayang. "25

Ketiga, bahwa manusia sebagai kepercayaan Tuhan, sekalipun resikonya besar. Surat al-Ahzab ayat 72:

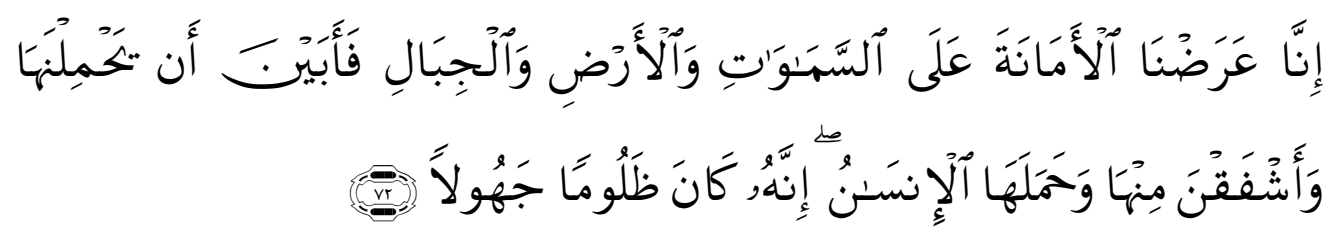

“ Sesungguhnya Kami telah mengemukakan amanat kepada langit, bumi dan gunung-gunung, maka semuanya enggan untuk memikul amanat itu dan mereka khawatir akan mengkhianatinya, dan dipikullah amanat itu oleh manusia. Sesungguhnya manusia itu amat zalim dan amat bodoh,"

Keempat, untuk itu manusia kemudian diberi kemampuan untuk mengetahui semua nama dan konsep benda yang malaikat sendiri tidak mampu. Karena itu malaikat sujud dan hormat kepadanya. Dalam surat $A l$ Baqarah ayat 31 :

\footnotetext{
${ }^{24}$ M.Quraish Shibab, Tafsir Al-Misbah Vol 1, (Jakarta, Lentera Hati, 2012), h. 173

25 Ibid, h. 202
} 


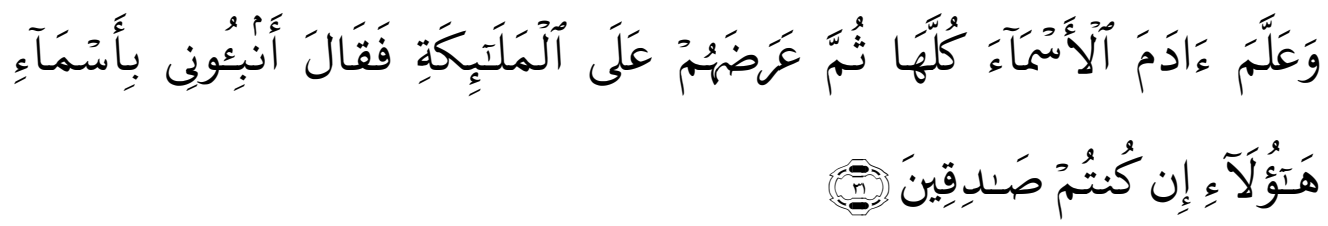

"Dan Dia mengajarkan kepada Adam nama-nama (benda-benda) seluruhnya, kemudian mengemukakannya kepada para Malaikat lalu berfirman: "Sebutkanlah kepada-Ku nama benda-benda itu jika kamu mamang benar orang-orang yang benar!"

Ayat ini menginformasikan bahwa manusia dianugerahi Allah potensi untuk mengetahui nama atau fungsi dan karakteristik benda-benda, misalnya fungsi api, fungsi angin dan sebagainya. Dia juga dianugerahi potensi untuk berbahasa. Sistem pengajaran bahasa kepada manusia (anak kecil) bukan dimulai dengan mengajarkan kata kerja, tetapi mengajarnya terlebih dahulu nama-nama. ${ }^{26}$

Dengan ini jelas bahwa ada empat sifat manusia yang diberikan kepada manusia, yaitu:

1. Manusia adalah mahkluk terpilih

2. Sebagai khalifah Allah di bumi

3. Diberikan kepercayaan melaksanakan amanat yang semua makhluk tidak tersedia

4. Manusia diberi kemampuan mengetahui nama semua benda, yang malaikat pun tidak tahu. ${ }^{27}$

\section{Tugas Khalifah}

Agama Islam mengajarkan bahwa manusia memiliki dua predikat, yaitu sebagai hamba Allah ('abdullah) dan sebagai wakil Allah (khalifatullah) di muka bumi. Sebagai hamba Allah, manusia adalah kecil dan tak memiliki kekuasaan. Oleh karena itu, tugasnya hanya menyembah kepada-Nya dan berpasrah diri kepada-Nya. Tetapi sebagai khalifatullah, manusia diberi fungsi sangat besar, karena Allah Maha Besar maka manusia sebagai wakilNya di muka bumi memiliki tanggung jawab dan otoritas yang sangat besar.

\footnotetext{
${ }^{26}$ M.Quraish Shibab, Tafsir Al-Misbah Vol 1 ......... h. 176

${ }^{27}$ H A. Mukti Ali, Memahami Beberapa Aspek Ajaran Islam, (Bandung, Mizan, 1996), h. 
Sebagai khalifah, manusia diberi tangung jawab pengelolaan alam semesta untuk kesejahteraan umat manusia, karena alam semesta memang diciptakan Tuhan untuk manusia. Sebagai wakil Tuhan manusia juga diberi otoritas ketuhanan; menyebarkan rahmat Tuhan, menegakkan kebenaran, membasmi kebatilan, menegakkan keadilan, dan bahkan diberi otoritas untuk menghukum mati manusia. Sebagai hamba manusia adalah kecil, tetapi sebagai khalifah Allah, manusia memiliki fungsi yang sangat besar dalam menegakkan sendi-sendi kehidupan di muka bumi. Oleh karena itu, manusia dilengkapi Tuhan dengan kelengkapan psikologis yang sangat sempurna, akal, hati, syahwat dan hawa nafsu, yang kesemuanya sangat memadai bagi manusia untuk menjadi makhluk yang sangat terhormat dan mulia, disamping juga sangat potensil untuk terjerumus hingga pada posisi lebih rendah dibanding binatang. Hal ini sejalan dengan surah al-Hajj ayat 41

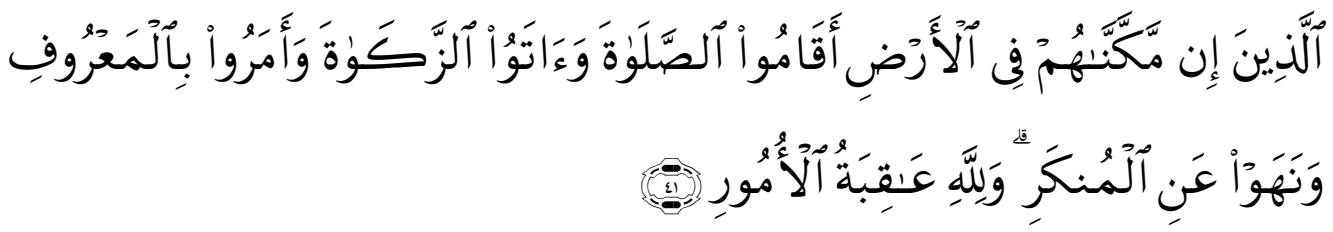

(yaitu) orang-orang yang jika Kami teguhkan kedudukan mereka di muka bumi niscaya mereka mendirikan sembahyang, menunaikan zakat, menyuruh berbuat ma'ruf dan mencegah dari perbuatan yang mungkar; dan kepada Allah-lah kembali segala urusan. ${ }^{28}$

Dalam ayat ini di tafsirkan bahwa Allah menjanjikan akan menolong orang-orang yang menolong agama-Nya, yaitu orang-orang yang apabila dimenangkan atas musuh-musuhnya dan diteguhkan kedudukannya sebagai penguasa atau pemimpin, bertambah tekun dan rajin melaksanakan perintahperintah Allah, mendirikan sembahyang, menunaikan zakat, menyuruh orang berbuat makruf dan melarang orang berbuat mungkar. Dan kepada Allahlah

28 Departemen Agama, Alquran.... h. 469 
kembali segala sesuatu dan dari pada-Nya-lah akan diterima pembalasan atas segala amal dan perbuatan. ${ }^{29}$

Mendirikan shalat merupakan gambaran dari hubungan yang baik dengan Allah, sedangkan menunaikan zakat merupakan gambaran dari keharmonisan dengan sesame manusia. Ma'ruf adalah suatu istiah yang berkaitan dengan segala sesuatu yang dianggap baik oleh agama, akal dan budaya, dan sebaliknya dari mungkar.

Selain itu juga ayat yang lain tentang tugas khalifah dalam mencegah kemungkaran dalam surat An-Nahl ayat 125:

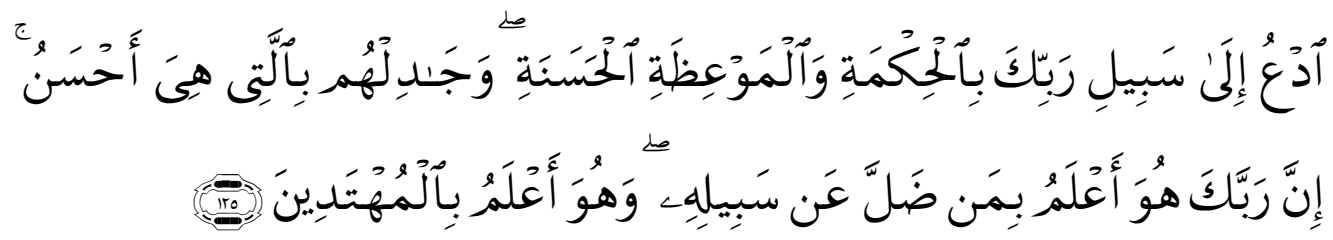

"Serulah (manusia) kepada jalan Tuhan-mu dengan hikmah" dan pelajaran yang baik dan bantahlah mereka dengan cara yang baik. Sesungguhnya Tuhanmu Dialah yang lebih mengetahui tentang siapa yang tersesat dari jalan-Nya dan Dialah yang lebih mengetahui orang-orang yang mendapat petunjuk."

Selain ayat diatas terdapat hadis nabi yang membicarakan tentang amar makruf nahi mungkar sebagaimana hadis berikut ini:

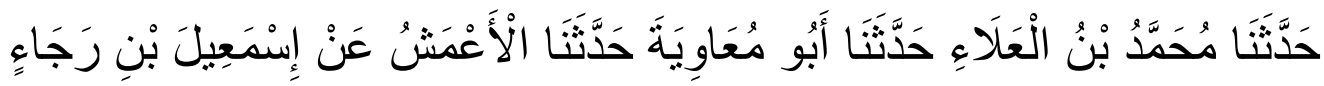

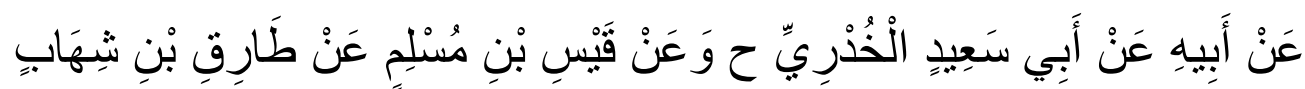

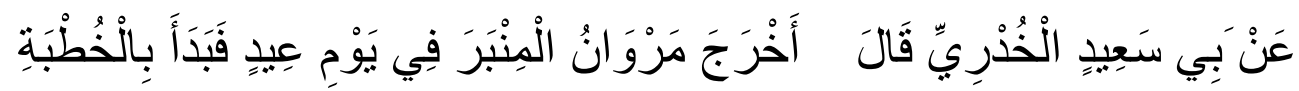

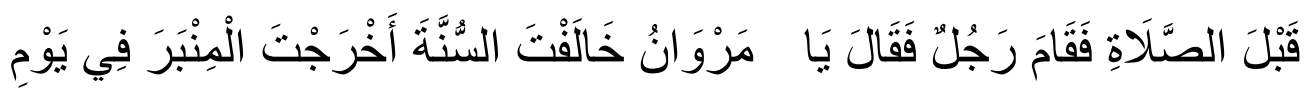

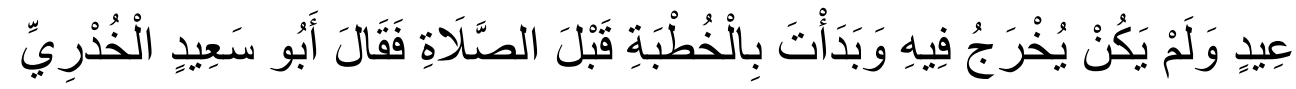

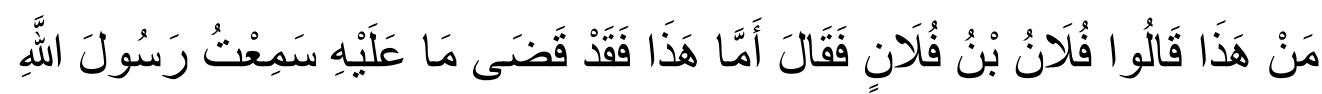

\footnotetext{
${ }^{29}$ H. Salim Bahreisy dan H Said Bahreisy, Terjemah Singkat Tafsir Ibnu Katsier, Jilid V, ( Surabaya, PT. Bina Ilmu, tt), h. 376

${ }^{30}$ Hikmah: ialah perkataan yang tegas dan benar yang dapat membedakan antara yang hak dengan yang bathil.
} 


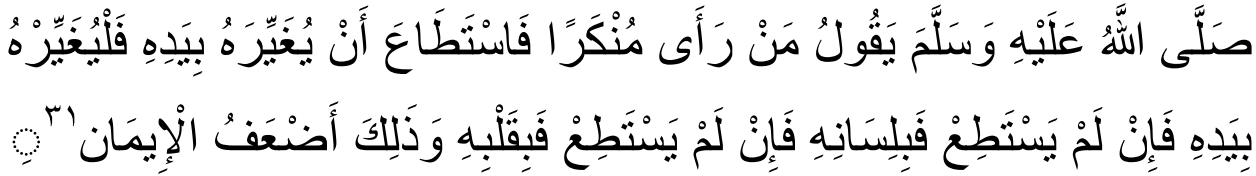

"Telah menceritakan kepada kami Muhammad bin Al 'Ala' telah menceritakan kepada kami Abu Mu'awiyah telah menceritakan kepada kami Al A'masy dari Isma'il bin Raja dari ayahnya dari Abu Sa'id Al Khudri. Dan telah di riwayatkan dari jalur lain, dan dari Qais bin Muslim dari Thariq bin Syihab dari Abu Sa'id Al Khudri dia berkata; "Marwan pernah mengeluarkan mimbar pada waktu hari raya, lalu dia mulai khutbah sebelum shalat, maka seorang laki-laki berdiri dan berkata; "Wahai Marwan, kamu telah menyelisihi sunnah, kamu telah mengeluarkan mimbar pada hari raya, padahal mimbar belum pernah sama sekali di keluarkan, dan kamu juga memulai khutbah sebelum shalat." Abu Sa'id Al Khudri berkata; "Siapakah laki-laki ini?" mereka menjawab; "Fulan bin fulan." Abu Sa'id berkata; "Orang ini telah melaksanakan kewajibannya ('Amar ma'ruf dan nahi munkar), aku mendengar Rasulullah shallallahu 'alaihi wasallam bersabda: "Barangsiapa melihat kemungkaran, hendaklah semampunya ia merubah dengan tangannya, jika tidak mampu, maka dengan lisannya, dan jika tidak mampu, maka dengan hatinya, dan yang demikian itu adalah selemah-lemah iman. ${ }^{132}$

Selain itu juga terdapat hadis lain

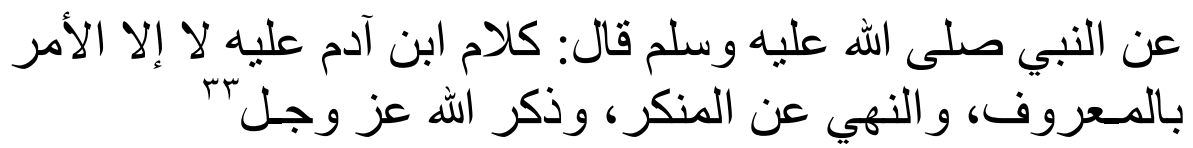

Artinya: ucapan anak adam itu akan kembali dengan membawa bencana untuknya dan tidak membawa keberuntungan baginya, kecuali amar ma'ruf dan nahi mungkar, serta berdzikir kepada Allah 'azza wajalla.

Secara umum, tugas Khalifah itu ialah :

1. Tamkin Dinillah (menegakkan agama Allah) yang telah diridhai-Nya dengan menjadikannya sistem hidup dan perundangan-undangan dalam semua aspek kehidupan. Terdapat dalam surah as-Shaff ayat 14

31 Abu> Da>wud Sulaiman bin Al-Asy'ats As-Sijista>ni>, Sunan Abu>Da>wud, (Beirut, Darul Fikri, 1999), h. 423

${ }^{32}$ Syekh Manshur Ali Nashi>f, At Taju Jamiul Ushuli Fi Ahadist Rosuli: Mahkota Pokokpoko hadist Rasulullah, (Bandung, Sinar Baru Algesindo), h. 661

${ }^{33} \mathrm{Abu}>$ Abdullah muhammad bin yazi>d al Qazwaini as Syahi>r bi Ibnu Majah, Sunan Ibnu Majah, (Riyad, Maktabah al Ma'a>rif,tt), h. 656 


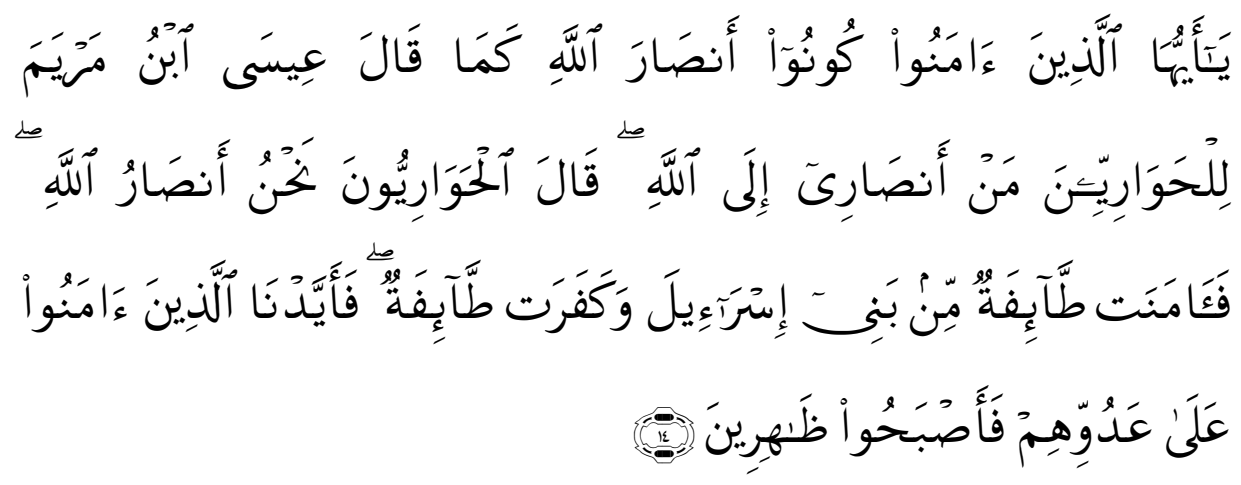

Hai orang-orang yang beriman, jadilah kamu penolong (agama) Allah sebagaimana Isa Ibnu Maryam telah berkata kepada pengikutpengikutnya yang setia: "Siapakah yang akan menjadi penolongpenolongku (untuk menegakkan agama) Allah?" Pengikut-pengikut yang setia itu berkata: "Kamilah penolong-penolong agama Allah", lalu segolongan dari Bani Israil beriman dan segolongan lain kafir; Maka Kami berikan kekuatan kepada orang-orang yang beriman terhadap musuh-musuh mereka, lalu mereka menjadi orang-orang yang menang.

2. Menciptakan keamanan bagi umat Islam dalam menjalankan agama Islam dari ancaman orang-orang kafir, baik yang berada dalam negeri Islam maupun yang di luar negeri Islam. Surah an-Nisa ayat 83

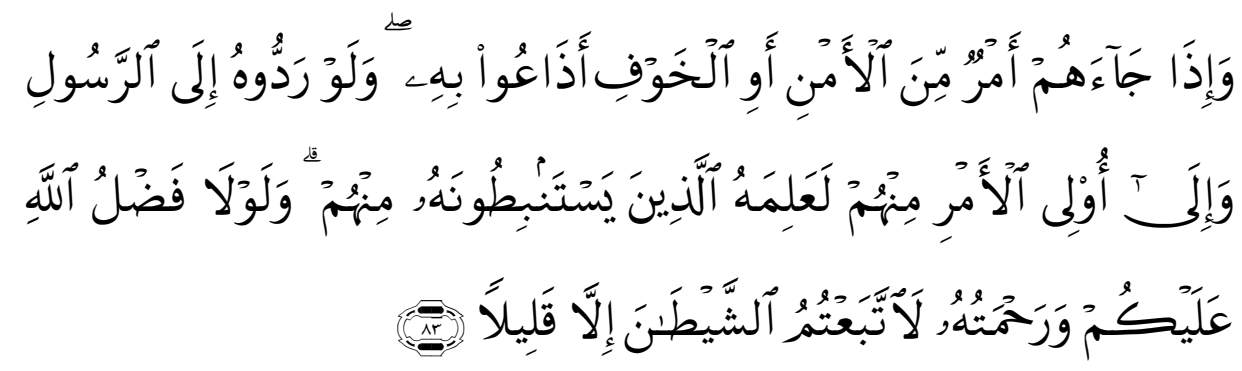

dan apabila datang kepada mereka suatu berita tentang keamanan ataupun ketakutan, mereka lalu menyiarkannya. dan kalau mereka menyerahkannya kepada Rasul dan ulil Amri[322] di antara mereka, tentulah orang-orang yang ingin mengetahui kebenarannya (akan dapat) mengetahuinya dari mereka (Rasul dan ulil Amri)[323]. kalau tidaklah karena karunia dan rahmat Allah kepada kamu, tentulah kamu mengikut syaitan, kecuali sebahagian kecil saja (di antaramu).

3. Menegakkan sistem ibadah dan menjauhi sistem dan perbuatan syirik, sesuai firman Allah swt dalam surah An nur ayat 55 


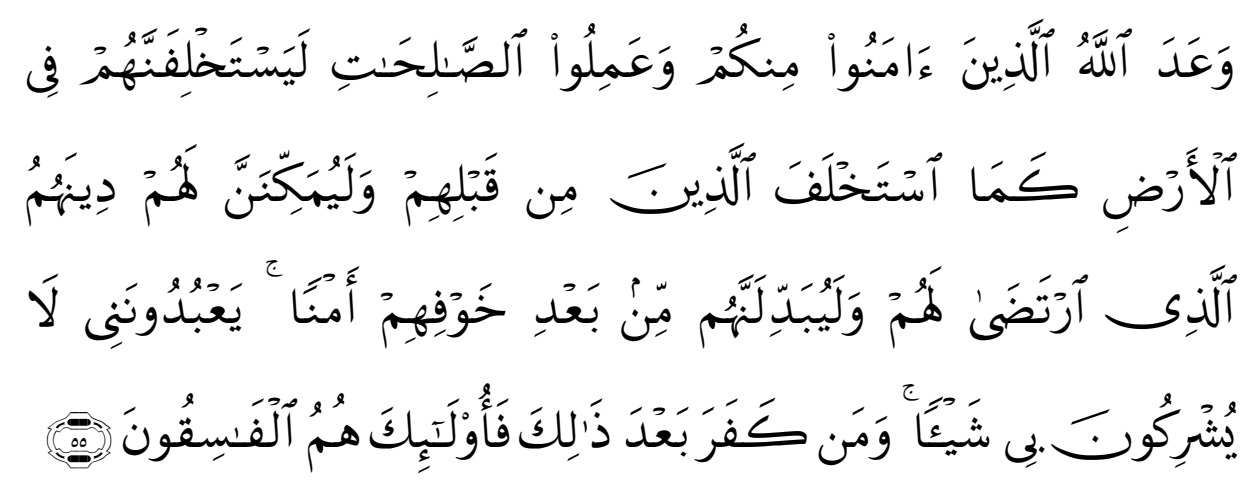

dan Allah telah berjanji kepada orang-orang yang beriman di antara kamu dan mengerjakan amal-amal yang saleh bahwa Dia sungguhsungguh akan menjadikan mereka berkuasa dimuka bumi, sebagaimana Dia telah menjadikan orang-orang sebelum mereka berkuasa, dan sungguh Dia akan meneguhkan bagi mereka agama yang telah diridhai-Nya untuk mereka, dan Dia benar-benar akan menukar (keadaan) mereka, sesudah mereka dalam ketakutan menjadi aman sentausa. mereka tetap menyembahku-Ku dengan tiada mempersekutukan sesuatu apapun dengan aku. dan Barangsiapa yang (tetap) kafir sesudah (janji) itu, Maka mereka Itulah orang-orang yang fasik. $^{34}$

4. Menerapkan undang-undang yang ada dalam Al-Qur'an, termasuk Sunnah Rasul Saw. dengan Haq dan adil, kendati terhadap diri, keluarga dan orang-orang terdekat sekalipun. Hal ini terdapat dalam surah an-Nisa ayat 135:

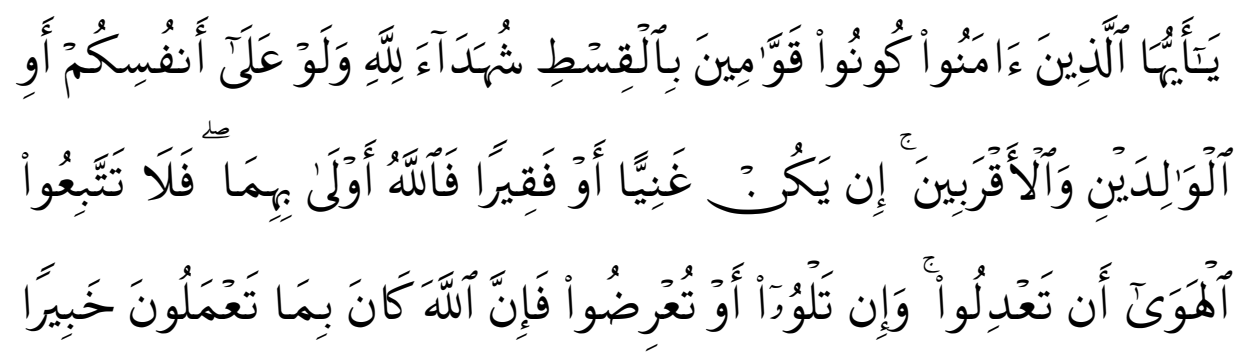

Wahai orang-orang yang beriman, jadilah kamu orang yang benarbenar penegak keadilan, menjadi saksi karena Allah biarpun terhadap
${ }^{34}$ Departemen Agama, Alquran h. 498 
dirimu sendiri atau ibu bapa dan kaum kerabatmu. jika ia Kaya ataupun miskin, Maka Allah lebih tahu kemaslahatannya. Maka janganlah kamu mengikuti hawa nafsu karena ingin menyimpang dari kebenaran. dan jika kamu memutar balikkan (kata-kata) atau enggan menjadi saksi, Maka Sesungguhnya Allah adalah Maha mengetahui segala apa yang kamu kerjakan.

Selain itu juga terdapat dalam surah al-Maidah ayat 8:

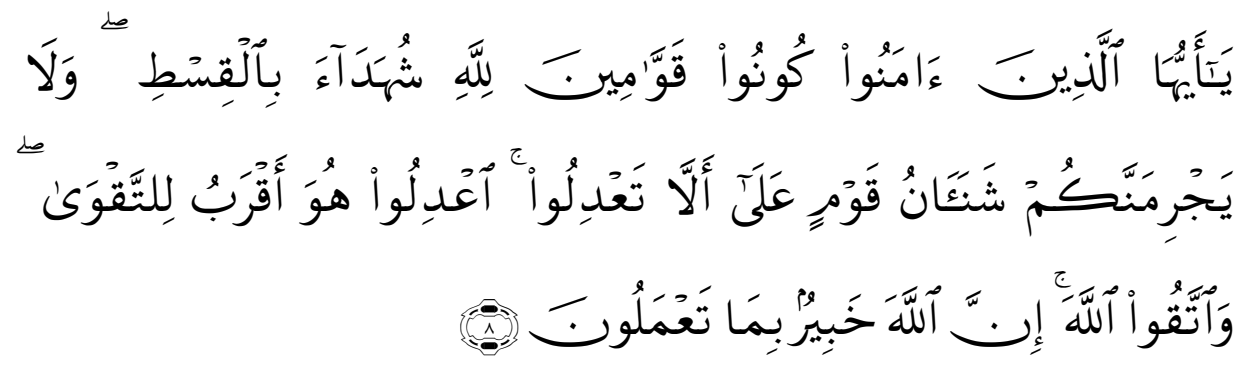

Hai orang-orang yang beriman hendaklah kamu Jadi orang-orang yang selalu menegakkan (kebenaran) karena Allah, menjadi saksi dengan adil. dan janganlah sekali-kali kebencianmu terhadap sesuatu kaum, mendorong kamu untuk Berlaku tidak adil. Berlaku adillah, karena adil itu lebih dekat kepada takwa. dan bertakwalah kepada Allah, Sesungguhnya Allah Maha mengetahui apa yang kamu kerjakan.

5. Berjihad di jalan Allah. ${ }^{35}$ Hal ini sesuai dengan firman Allah dalam surat at-Taubah ayat 38:

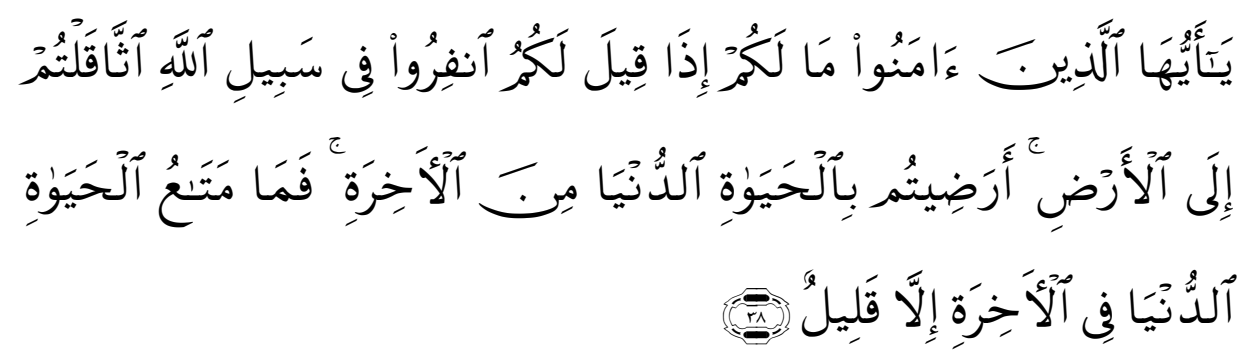

"Hai orang-orang yang beriman, Apakah sebabnya bila dikatakan kepadamu: "Berangkatlah (untuk berperang) pada jalan Allah" kamu

${ }^{35}$ http://www.eramuslim.com/berita/laporan-khusus/antara-khilafah-dan khalifah.htm\#.VEj8ZxbGxqg diakses tanggal 20 Oktober 2014 
merasa berat dan ingin tinggal di tempatmu? Apakah kamu puas dengan kehidupan di dunia sebagai ganti kehidupan di akhirat? Padahal kenikmatan hidup di dunia ini (dibandingkan dengan kehidupan) diakhirat hanyalah sedikit"

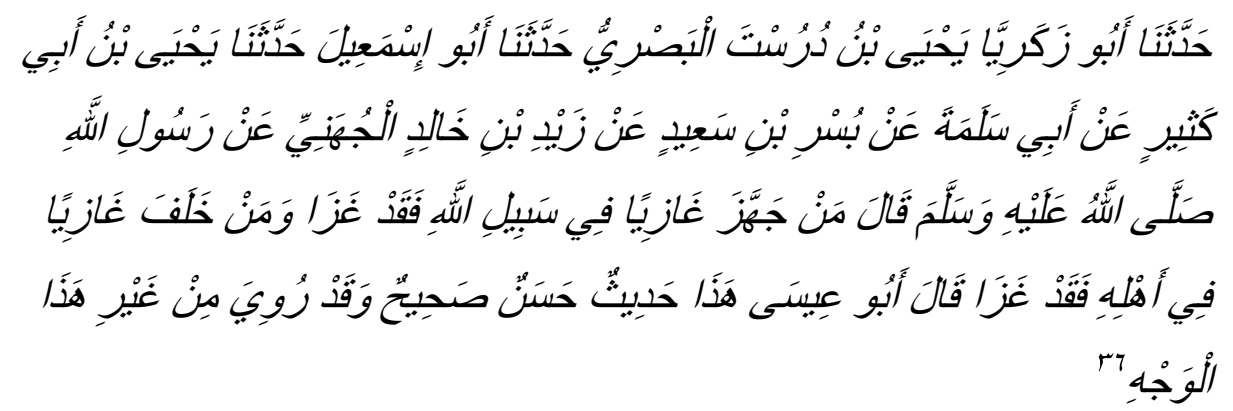

Telah menceritakan kepada kami Abu Zakariya Yahya bin Durusta Al Bashri berkata, telah menceritakan kepada kami Abu Isma'il berkata, telah menceritakan kepada kami Yahya bin Abu Katsir dari Abu Salamah dari Busr bin Sa'id dari Zaid bin Khalid Al Juhani dari Rasulullah shallallahu 'alaihi wasallam, beliau bersabda: "Barangsiapa menyediakan bekal kepada seorang mujahid di jalan Allah maka ia telah berjihad. Dan barangsiapa menanggung keluarga orang yang berjihad, maka ia telah berjihad." Abu Isa berkata, "Hadits ini derajatnya hasan shahih, hadits ini juga telah diriwayatkan dari selain jalur ini".

\section{E. Syarat-syarat Khalifah}

Karena Khalifah itu adalah pemimpin tertinggi umat Islam, bukan hanya pemimpin kelompok atau jamaah umat Islam tertentu, dan bertanggung jawab atas tegaknya ajaran Islam dan ururusan duniawi umat Islam, maka para ulama, baik salaf (generasi awal Islam) maupun khalaf (generasi setelahnya), telah menyepakati bahwa seorang Khalifah itu harus memiliki syarat atau kriteria yang sangat ketat. Syarat atau kriteria yang mereka jelaskan itu berdasarkan petunjuk Alquran, Sunnah Rasul saw. dan juga praktek sebagian Sahabat, khususnya Khulafaur rasyidin setelah Rasul saw, yakni Abu Bakar, Umar, Utsman dan Ali, radhiyallahu 'anhum ajma'in.

36 Muhammad bin Isa bin Saurah AtTirmizi>, Sunan At Tirmizi>, (Riyad, Mukatabah Ma'arif, cet $1, \mathrm{tt})$, h. 383 
Menurut Syekh Muhammad Al-H<asan Addud Asy-Syangqiti, paling tidak ada sepuluh syarat atau kriteria yang harus terpenuhi oleh seorang Khalifah :

1. Muslim. Tidak sah jika ia kafir, munafik atau diragukan kebersihan akidahnya.

2. Laki-Laki. Tidak sah jika ia perempuan karena Rasul saw bersabda : Tidak akan sukses suatu kaum jika mereka menjadikan wanita sebagai pemimpin.

Hal ini sesuai dengan firman Allah swt dalam surah An-Nisaa ayat 34:

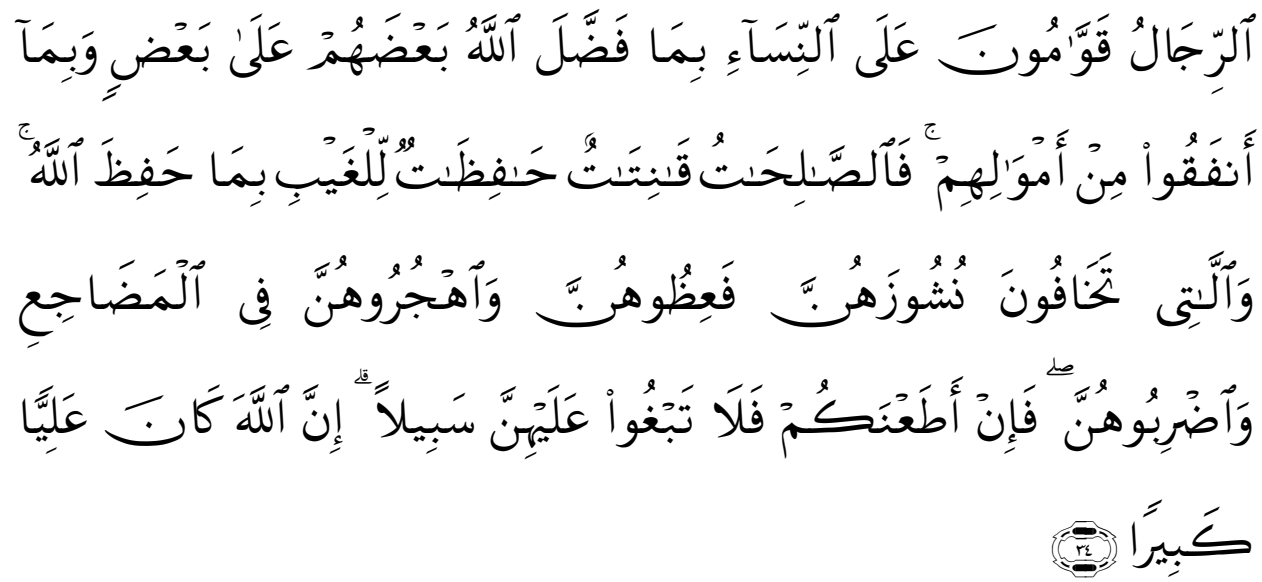

"kaum laki-laki itu adalah pemimpin bagi kaum wanita", oleh karena Allah telah melebihkan sebahagian mereka (laki-laki) atas sebahagian yang lain (wanita), dan karena mereka (laki-laki) telah menafkahkan sebagian dari harta mereka. sebab itu Maka wanita yang saleh, ialah yang taat kepada Allah lagi memelihara diri ketika suaminya tidak ada, oleh karena Allah telah memelihara (mereka). wanita-wanita yang kamu khawatirkan nusyuznya, Maka nasehatilah mereka dan pisahkanlah mereka di tempat tidur mereka, dan pukullah mereka. kemudian jika mereka mentaatimu, Maka janganlah kamu mencari-cari jalan untuk menyusahkannya. Sesungguhnya Allah Maha Tinggi lagi Maha besar". 38

37 Artinya laki-laki mempunyai kekuasaan terhadap perempuan dan berkewajiban mendidik dan membimbing mereka. Imam Jalaluddin Al-Mahali dan Imam Jalaluddin As-Suyuthi, Tafsir Jalalain Jilid 1 ......, h. 330

${ }^{38}$ Departemen Agama, Al qur'an.......h. 108 
Selain ayat diatas terdapat hadis nabi yang mengemukakan bahwa perempuan tidak bisa sebagai pemimpin

أخبرنا محمـد بن المثنى، قال: حدثنا خالد بن الحارث، قال: حدثنا حميد

عن الحسن عن أبي بكرة، قال: رسول الله صلى الله عليه وسلم: لنْ يُفْلحَ

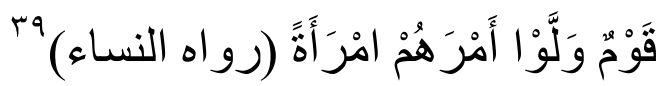

Artinya: Telah menceritakan kepada kami 'Muhammad bin Musanna, telah menceritakan kepada kami Kholid bin haris, telah menceritakan kepadakami hamid dari hasan dari abi Bakrah berkata Rasulullah saw Tak akan baik keadaan sebuah kaum yang mengangkat wanita sebagai pemimpin urusan mereka." (HR. an-Nasai)

3. Merdeka. Tidak sah jika ia budak, karena ia harus memimpin dirinya dan orang lain. Sedangkan budak tidak bebas memimpin dirinya, apalagi memimpin orang lain.

4. Dewasa. Tidak sah jika anak-anak, kerena anak-anak itu belum mampu memahami dan memecahkan permasalahan.

5. Sampai ke derajat Mujtahid. Kerena orang yang bodoh atau berilmu karena ikut-ikutan (taklid), tidak sah kepemimpinannya seperti yang dijelaskan Ibnu Hazm, Ibnu Taimiyah dan Ibnu Abdul Bar bahwa telah ada ijmak (konsensus) ulama bahwa tidak sah kepemimpinan tertinggi umat Islam jika tidak sampai ke derajat Mujtahid tentang Islam.

6. Adil. Tidak sah jika ia zalim dan fasik, karena Allah menjelaskan kepada Nabi Ibrahim bahwa janji kepemimpinan umat itu tidak (sah) bagi orangorang yang zalim. Seorang pemimpin diharuskan bersikap adil dalam menjalankan kepemimpinannya. Karena kepemimpinan yang kita jalankan akan diminta pertanggungjawabannya oleh yang maha kuasa,

${ }^{39}$ Abi $>$ Abd-Rahma>n Ahmad Bin Syu'aib bin Ali> al-Syahi $>$ r bi an-Nasa $>\mathrm{i}$,Sunan Nasa $>i$ (Riya>d, Maktabah al-Ma'a>rif, tt), h. 809 


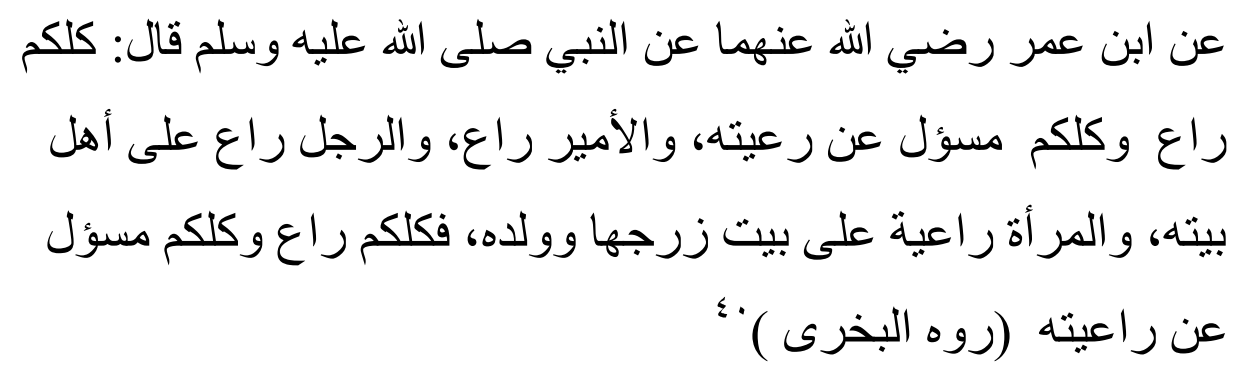

Artinya, dari ibnu umar ra dari Nabi saw berkata: setiap kamu adalah pemimpin dan setiap pemimpin akan ditanya dari apa yang dipimpinnya. Dan setiap pemimpin (dalam suatu negara) adalah pemimpin, dan lakilaki adalah pemimpin atas keluarganya, dan perempuan adalah pemimpin atas rumah suaminya dan anak-anaknya, maka setiap kamu adalah pemimpin dan setiap pemimpin akan ditanya tentang apa yang dipimpinnya.

7. Profesional (amanah dan kuat). Khilafah itu bukan tujuan, akan tetapi sarana untuk mencapai tujuan-tujuan yang disyari'atkan seperti menegakkan agama Allah di atas muka bumi, menegakkan keadilan, menolong orang-orang yang yang dizalimi, memakmurkan bumi, memerangi kaum kafir, khususnya yang memerangi umat Islam dan berbagai tugas besar lainnya. Orang yang tidak mampu dan tidak kuat mengemban amanah tersebut tidak boleh diangkat menjadi Khalifah Sebab itu, Imam Ibnu Badran, rahimahullah, menjelaskan bahwa pemimpin-pemimpin Muslim di negeri-negeri Islam yang menerapkan sistem kafir atau musyrik, tidaklah dianggap sebagai pemimpin umat Islam karena mereka tidak mampu memerangi musuh dan tidak pula mampu menegakkan syar'ait Islam dan bahkan tidak mampu melindungi orang-orang yang dizalimi dan seterusnya, kendatipun mereka secara formal memegang kendali kekuasaan seperti raja tau presiden. Lalu Ibnu Badran menjelaskan : Mana mungkin orang-orang seperti itu menjadi Khalifah, sedangkan mereka dalam tekanan Taghut (Sistem Jahiliyah) dalam semua aspek kehidupan.

40 Abu> Abdullah Muhammad Bin Isma'i>l al-Bukha>ri>, al Ja>mi' as Shahih, (Qa>hiroh, al-Maktabah as-Salafiyah,tt), h. 389 
8. Sehat penglihatan, pendengaran dan lidahnya dan tidak lemah fisiknya. Orang yang cacat fisik atau lemah fisik tidak sah kepemimpinannya, karena bagaimana mungkin orang seperti itu mampu menjalankan tugas besar untuk kemaslahatan agama dan umatnya? Untuk dirinya saja memerlukan bantuan orang lain.

9. Pemberani. Orang-orang pengecut tidak sah jadi Khalifah. Bagaimana mungkin orang pengecut itu memiliki rasa tanggung jawab terhadap agama Allah dan urusan Islam dan umat Islam? Ini yang dijelaskan Umar Ibnul Khattab saat beliau berhaji : Dulu aku adalah pengembala onta bagi Khattab (ayahnya) di Dhajnan. Jika aku lambat, aku dipukuli, ia berkata : Anda telah menelantarkan (onta-onta) itu. Jika aku tergesa-gesa, ia pukul aku dan berkata: Anda tidak menjaganya dengan baik. Sekarang aku telah bebas merdeka di pagi dan di sore hari. Tidak ada lagi seorangpun yang aku takuti selain Allah.

10. Dari suku Quraisy, yakni dari puak Fihir Bin Malik, Bin Nadhir, Bin Kinanah, Bin Khuzai'ah. Para ulama sepakat, syarat ini hanya berlaku jika memenuhi syarat-sayarat sebelumnya. Jika tidak terpenuhi, maka siapapun di antara umat ini yang memenuhi persayaratan, maka ia adalah yang paling berhak menjadi Khalifah. ${ }^{41}$

\section{F. Kesimpulan}

Dari pembahasan yang telah diuraikan di atas dapat diambil kesimpulan bahwa dalam konsep Islam, manusia adalah khalifah yakni sebagai wakil, pengganti atau duta Tuhan di muka bumi. dengan kedudukannya sebagai khalifah Allah swt dimuka bumi, manusia akan dimintai tanggungjawab dihadapannya. Tentang bagaimana ia melaksanakan tugas suci kekhalifahannya. Oleh sebab itu dalam melaksanakan tanggungjawab itu manusia dilengkapi dengan berbagai potensi seperti akal pikiran yang memberikan kemampuan bagi manusia berbuat demikian.

\footnotetext{
${ }^{41}$ http://www.eramuslim.com/berita/laporan-khusus/antara-khilafah-dan khalifah.htm\#.VEj8ZxbGxqg diakses tanggal 20 Oktober 2014
} 
Kata khalifah juga mengandung makna pengganti nabi Muhammad saw dalam fungsinya sebagai kepala Negara, yaitu pengganti Nabi Saw dalam jabatan kepala pemerintahan dalam Islam baik urusan agama maupun dunia

Ada empat sifat manusia yang diterangkan dalam al-qur'an:

1. bahwa manusia itu adalah mahkluk yang dipilih oleh Tuhan. Hal ini sesuai dengan firman Allh dalam surat Tahaa ayat 122'

2. manusia dengan segala kelalaiannya diharapkan supaya menjadi wakil tuhan di bumi (khalifah). Hal in terdapat dalam surat al-Baqarah ayat 30,

3. bahwa manusia sebagai kepercayaan tuhan, sekalipun risikonya besar. Hal ini terkandung dalam Surat al-Ahzab ayat 72,

4. untuk itu manusia kemudian diberi kemampuan untuk mengetahui semua nama dan konsep benda yang malaikat sendiri tidak mampu. Karena itu malaikat sujud dan hormat kepadanya, hal ini sesuai dengan firman Allah swt dalam surat Al-Baqarah ayat 31.

\section{Daftar Pustaka}

al-Bukha>ri Abu> Abdullah Muhammad Bin Isma'i>l al-Bukha>ri>, al $J a>m i$ ' as Shahih, Qa>hirah, al-Maktabah as-Salafiyah,tt

an-Nasa>i Abi> Abd-Rahman Ahmad Bin Syu'aib bin Ali> al-Syahi>r bi anNasa>i ,Sunan Nasa>i,Riya>d, Maktabah al-Ma'a>rif, tt

Abu> Dawud Sulaiman bin Al-Asy'ats As-Sijistani>, Sunan Abu>Da>wud, Beirut, Darul Fikri, 1999 
Al-Ashfahani Ar-Raghib, Al-Mufradat fi Gharib Alqur'an, Tanpa Kota: Maktabah Nazar Musthofa al-Baz, Juz 1,tt

Al-Damaghoni Al-Husain Ibn Muhammad, Qamus Al-Quran aw Ishlah alUWujuh wa an-Nazhair fi Alquran al-Karim, Beirut: Dar'ilmi lil Malayin, 1980)

Al-Mahali Imam Jalaluddin dan As-Suyuthi Imam Jalaluddin, Tafsir Jalalain Jilid 1, Bandung, Sinar Baru Algensindo, 2014

Al-Mahali Imam Jalaluddin dan As-Suyuthi Imam Jalaluddin, Tafsir Jalalain Jilid 2, Bandung, Sinar Baru Algensindo, 2014

Ali H A. Mukti, Memahami Beberapa Aspek Ajaran Islam, Bandung, Mizan, 1996

Ali Nashif Syekh Manshur, At Taju Jamiul Ushuli Fi Ahadist Rosuli:Mahkota Pokok-pokok hadist Rasulullah, Bandung, Sinar Baru Algesindo

AtTirmizi Muhammad bin Isa bin Saurah AtTirmizi>, Sunan At Tirmizi>, Riyad, Mukatabah Ma'arif, cet 1, tt

Bahreisy H. Salim dan H Said Bahreisy, Terjemah Singkat Tafsir Ibnu Katsier, Jilid V, Surabaya, PT. Bina Ilmu, tt

Departemen Agama, Al-Qur'an dan Terjemahan, Surabaya, Mekar Surabaya, 2004

Ibnu Majah Abu> Abdullah muhammad bin yazi>d al Qozwaini al- Syahir bi Ibnu Majah, Sunan Ibnu Maja>h, Riyad, Maktabah al ma'arif,tt

Lajnah Pentashihan Mushaf Al-Qur'an, Tafsir Al-qur'an Tematik :Spritualitas dan Ahklak, Jakarta, Aku Bisa, 2012

Dewan Redaksi Ensiklopedi Islam, Ensiklopedi Islam Jiid 3, Jakarta, PT Ichtiar Baru van Hoeve, 2003

Shihab M. Quraish, Wawasan Al-Quran Tafsir Maudhu'i atas Pelbagai Persoalan Umat, Bandung, Mizan, 1996

Shihab M. Quraish, Membumikan Al-Qur'an, Bandung, Mizan, 2013 
Shihab Umar, Kontekstualitas Al-Qur,an; Kajian Tematik Ayat-ayat hukum dalam Al-Qur'an, Jakarta, Penamadani, 2005

Shibab M.Quraish, Tafsir Al-Misbah Vol 1, Jakarta, Lentera Hati, 2012

Yusuf Ali Abdullah, Qur'an Terjemahan dan Tafsirnya, Jakarta, Pustaka Pirdaus, 1993

http://www.eramuslim.com/berita/laporan-khusus/antara-khilafah-dankhalifah.htm\#.VEj8ZxbGxqg

http://www.darulquran-walirsyad.org/index.php/kajian-kitab/riyadhus$\underline{\text { shalihin }}$ 